\title{
The face of the party? Leader personalisation in British campaigns
}

\author{
Caitlin Milazzo \\ University of Nottingham \\ Nottingham, UK \\ Jesse Hammond \\ Naval Postgraduate School \\ Monterey, CA, USA
}

The personal characteristics of political elites play an important role in British elections. While the personalisation of the media's election coverage has been the subject of much debate, we know less about the conditions under which voters receive personalised messages directly from elites during the campaign. In this paper, we use a new dataset that includes more than 3,300 local communications from the 2015 general election to explore variation in the personalisation of campaign messaging. We find that there is systemic variation in terms of where photographs of party leaders are included in election communications, which provides further evidence that campaign messages are deployed strategically to portray the candidate - and their party - in the best possible light. 


\section{Introduction}

The personal attributes of political elites are now a common feature of electoral campaigns, even in the most party-centred of systems. ${ }^{1}$ The "personalisation" of politics is frequently attributed to two long-term factors: party dealignment and the changing nature of the media. With respect to the former, the ties between citizens and political elites have long been eroding in most western European democracies (e.g., Dalton and Wattenberg 2000; Berglund et al. 2005). As the traditional basis of party support has weakened, electorates have become more volatile. Political elites have been forced to consider new ways to attract support, and voters have become more willing to consider other factors, such as the personality and image of political elites, when deciding how to cast their ballot. The ability of voters to access - and make use of - personalised information has been greatly aided by the growing prevalence of electronic media, such as television, internet websites and newspapers, more recently, social media platforms such as Twitter and Facebook. $^{2}$

British elections are no exception. While there is some debate as to whether the media's coverage of election campaigns has become more personalised over time, ${ }^{3}$ there is widespread consensus that individual elites - and in particular, party leaders - now feature prominently in British media (see, Wring and Ward 2010). There is also ample evidence that evaluations of party leaders influence voting behaviour (e.g., Clarke et al. 2004, 2009; Evans and Andersen 2005;

\footnotetext{
${ }^{1}$ An online appendix with supplementary material is available at http://XXXX. The files necessary to reproduce the main numerical results are available at https://dataverse.harvard.edu. ${ }^{2}$ See McAllister (2007) for an excellent summary of these arguments.

${ }^{3}$ Dalton et al. (2000) find that the media coverage of candidate vis-à-vis parties increased between 1952 and 1997. Likewise, Deacon and Harmer (2014) conclude that presence of party leaders in newspapers has become more pronounced since 1951, particularly following the introduction of televised leadership debates in 2010. However, other studies conclude that the evidence in favour of increasing personalisation is mixed (see, Kriesi 2012; Karvonen 2010;
} Vliegenthart et al. 2011). 
Graetz and McAllister 1987) ${ }^{4}$ But, while much attention has been devoted to exploring the nature of personalised election coverage in the media (e.g., Kriesi 2012; Wring and Ward 2010), we know less about the personalisation of campaign materials.

In this paper, we use a new dataset comprised of more than 3,300 leaflets from the 2015 general election to explore the conditions under which party leaders feature in campaigns communications. ${ }^{5}$ Building on the literature that points to the increasingly targeted nature of modern election campaigns in Britain (e.g., Denver et al. 2004; Fisher et al. 2015; e.g., Pattie et al. 1995), we contend that the inclusion of political leaders is a strategic choice. Specifically, we argue that the decision to include a party leader will depend on the perceived popularity of the leader, as well as the local context and characteristics of the party's local candidate. Our findings suggest while that national popularity is the most significant determinant of whether party leaders feature in election communications, the local context also drives variation in the personalisation of campaign materials. Our findings are significant because they provide additional insight into important variation in the content of campaign material. They also provide further evidence that political elites are strategic in the messages that they disseminate to voters during the campaign.

In the following section, we present a new means of collecting data on the electoral communications distributed in British general elections that takes advantage of existing crowdsourced information. We then outline our expectations regarding variation in the personalisation of election communications. Finally, using our novel dataset, we gain new insights into how personalised content is employed by examining the conditions under which photographs of party leaders are included in election leaflets.

\footnotetext{
${ }^{4}$ In Britain, an increasing personalisation of politics can also be attributed to the growing presidentialisation of the British premiership, particularly under Tony Blair (Foley 2000; Heffernan and Webb 2005).

${ }^{5}$ Any communications that are sent to voters via post are defined as "unsolicited materials" by the Electoral Commission. We use the terms "leaflets" and "electoral communications" interchangeably when referring to unsolicited materials.
} 


\section{Studying variation in campaign messaging}

Election communications inform voters about the qualifications of the party's local candidate and convey information about the policy positions of the candidate and/or the candidate's party. By providing this information, elites help voters to process campaign information by distilling complex political issues to concise bits of information that are easily processed and assimilated (Panagopoulos 2012). Indeed, providing such information is one of the core functions of local campaigns in Britain (Kavanagh 1970). But nothing says that all voters receive the same information. Exploring variation in Labour party communications in Scotland during the 2001 and 2005 general elections, Shephard (2007) finds evidence that variation in messages used by Scottish Labour was correlated with the socio-demographic characteristics of constituencies. Similarly, Fisher (2005) compares the campaign messages of the Conservative Party, the Labour Party and the Liberal Democrats during the 2005 general election. His analyses suggest that there is variation in the messages employed by the three main parties in terms of both the issues mentioned and the tone of the messages.

Both of these studies provide evidence of systematic variation in campaign messaging, but they also demonstrate the challenges associated with studying electoral communications in Britain. Candidates and parties are legally required to report how much they spend on unsolicited materials - which includes election leaflets and other communications that are sent to voters via post - but they are not required to provide information about what they say in those communications. Therefore, researchers must rely on other approaches to study variation in campaign messaging, such as contacting election agents (Shephard 2007) or relying on volunteers located within each constituency to collect the election materials that they receive (Fisher 2005). While we do not take issue with either approach, the high costs associated with these methods of data collection make it more difficult for communications to be monitored in many constituencies and across multiple elections. As a result, it is perhaps unsurprising that there have been no systematic analyses of election communications since these studies were published. 


\section{Creating a new dataset of crowdsourced election communications}

Gathering data on electoral leaflets from a large number of constituencies would be prohibitively difficult without the resources of the crowdsourced record-keeping website Electionleaflets.org (http://www.electionleaflets.org). This site is run by a non-profit organisation that urges users to photograph or scan leaflets they receive, and upload them to a centralised online repository. The result is a compilation of thousands of scanned leaflet images, making it the largest collection of British election communications in existence.

We limit our data collection to include only general election leaflets published by Britain's most competitive parties, defined as six of the seven parties that were invited to participate in the leaders' debates: the Conservative Party, the Labour Party, the Liberal Democrats, the UK Independence Party (UKIP), the Green Party, and the Scottish National Party (SNP). ${ }^{6}$ These parties are unique in that they (1) have the resources available to engage in campaigning across a wide range of constituencies, and (2) are mainstream political parties with broad policy platforms rather than single-issue parties relying on niche appeals. These parties have both the resources and the motivation to tailor their broader message differently to different local audiences. As such, they are a logical choice for our analysis of local communication strategies.

The final dataset contains 3,304 leaflets from the 2015 general election. ${ }^{7}$ While our dataset represents the largest collection of election leaflets to date, we acknowledge that it is a sample of convenience. These are self-reported data; there are no incentives or institutions encouraging citizens to upload their leaflets to the Electionleaflets repository, nor are parties required to report how many leaflets they disseminated. This means that we are unable to determine whether our sample is representative of larger population of leaflets distributed by parties in the run-up to

\footnotetext{
${ }^{6}$ All 6 parties won more than one million voters and they were the only parties to exceed this threshold. For the seventh party, the Plaid Cymru, we did not acquire sufficient leaflets to perform a reliable analysis.

${ }^{7}$ The distribution of leaflets across parties is presented in Table A1.
} 
the 2015 general election. That being said, we have no reason to believe that there is bias associated with the types of leaflets that individuals chose to upload. As we have stated previously, Electionleaflets is run by a non-partisan organisation. On the website, individuals are encouraged to upload any - and all - leaflets they receive, and we have no reason to believe that those who uploaded leaflets did so strategically. And while we are unable to determine whether our data constitutes a representative sample of the total number of leaflets sent out by parties, the distribution of leaflets across parties in the dataset is consistent with the patterns we observe in campaign spending. ${ }^{8}$

Figure 1 summarises the distribution of leaflets across constituencies. Our dataset includes leaflets from 429 constituencies, or 68 per cent of all seats contested in Britain in the 2015 election. ${ }^{9}$ When we compare candidate spending on unsolicited materials with the distribution of leaflets by party across constituencies, we see that for all parties except the SNP - for which we have relatively few leaflets - there is a positive correlation between candidate spending on unsolicited materials and the total number of leaflets we have from the candidate's party in the seat. ${ }^{10}$

\footnotetext{
${ }^{8}$ The largest share of the leaflets in our dataset were authored by the Labour party or Labour candidates. In total, Labour - and its candidates - spent nearly $£ 13$ million on unsolicited materials, a figure that outweighed the spending of any other party in this area. We have fewer leaflets for the Conservatives and Liberal Democrats, and both parties spent less on leaflets and other unsolicited materials. Our dataset contains far fewer leaflets for the minor parties, but these parties spent considerably less on unsolicited materials. Data on party and candidate spending is available at http://www.electoralcommission.org.uk/.

${ }^{9}$ Our data records a mean of 22 leaflets per constituency, with a range from 1 to 133.

${ }^{10}$ For each candidate we add the total spending on unsolicited materials during the long and short campaign and we compare this figure to the total number of leaflets we have for the candidate's party in the constituency. The correlations for the Conservative Party, the Labour Party, Liberal Democrats, the Green Party, and UKIP are 0.18, 0.22, 0.32, 0.51, and 0.18, respectively. In all cases, the correlations are statistically significant at $\mathrm{p}<0.05$. For the SNP the correlation is -0.05 , but $\mathrm{p}>0.05$.
} 
In other words, we have more communications from seats where candidates devoted a larger portion of their budget to unsolicited materials. ${ }^{11}$

[Figure 1 here]

\section{Measuring personalisation in election communications}

In order to explore variation in the personalisation of election communications, we manually code additional information about each leaflet's contents. 'Personalised' communications are those that related to individual political elites (Wattenberg 1994). Building on the literature that stresses the importance of personal appearance and image, we measure the personalisation of a communication by determining whether a leaflet contains a personalised photograph.

The conventional wisdom is that the average person spends very little time considering political matters, ${ }^{12}$ and thus, those crafting election communications have limited space to convey their message. Photographs convey a great deal of information in a concise manner. In addition to information about demographic characteristics - such as age or gender - images also lead voters to form impressions and opinions about political elites (Verser and Wicks 2006) or solicit an emotional response (Marcus and MacKuen 1993). Moreover, even a quick glance a photograph is sufficient to form the type of first-impression judgements that are well-known to influence social decisions (e.g., Ambady and Rosenthal 1993; Hamermesh and Biddle 1994; Olson and Marshuetz 2005). Not only are these 'snap' judgements accurate predictors of election outcomes (e.g., Todorov et al. 2005; Mattes and Milazzo 2014), they are also resistant to change (Redlawsk 2002). Finally, individuals who are less interested in politics may be particularly inclined to use appearance when determining their vote choice (Johns and Shephard 2011; Lenz and Lawson 2011).

\footnotetext{
${ }^{11}$ This category of campaign spending includes all costs that result from the design, preparation, production and distribution of unsolicited materials. For a further discussion of the potential bias issue and additional robustness checks, see the online appendix.

12 Jim Messina, who signed on as a campaign strategy advisor to the Conservative Party in 2013, famously warned that average person thinks about politics for just four minutes a week.
} 
Therefore, even those not inclined to read their leaflets closely may be able to form an impression based on the photographs contained within them.

Two types of political elites should feature prominently in election communications: party leaders and candidates. In this paper, we focus solely on the presence of the party leader for two reasons. First, all else being equal, we would expect candidate photographs to be included frequently in leaflets. Leaders are more visible and well-known, and they are less in need of local publicity to raise their profile. Therefore, much of the campaign literature voters receive should be tailored to raising the profile and name recognition of the local candidate, who will be less familiar to voters. Second, the cost of any unsolicited materials that mention, or promote the election of, a local candidate will be counted against the candidate's election spending. Of the more than 3,300 leaflets we examined, more than 80 per cent mentioned the party's local candidate, and therefore, we can reasonably conclude that the vast majority of election communications are paid for by the candidates, rather than their party. Any attention devoted to - or images of - the party leader inevitably reduces the space that a candidate can devote to raising her own profile.

Many candidates will have limited funds to devote to their campaign, and even candidates with a more extensive 'war chest' will face legally mandated spending limits. In either case, a candidate will need to be strategic on how she uses her communications. ${ }^{13}$ She may wish to publicise her party leader - particularly if the leader is perceived to be an electoral asset - but increas-

\footnotetext{
${ }^{13}$ It is important to note that candidates frequently do not have full control over the design of their election communications. Leaflet design is often overseen by the central party organisation. Candidates and local party elites may be able to personalise the content, but the design is often consistent across constituencies.
} 
ing her own profile will be her first priority. Therefore, the interesting question is not why a candidate would choose to include her own image, but rather, under what conditions would she choose to sacrifice space in her leaflets to devote attention to her party leader? ${ }^{14}$

\section{Leader personalisation in election communications: Theory and hypotheses}

Margaret Thatcher's resignation as Conservative Party leader - and Prime Minister - initiated a period of British politics that was characterised by increasing policy convergence between the elites of the Labour and Conservative parties. As it became more difficult for voters to differentiate between the major parties on policy grounds, scholars began to emphasise the importance of non-policy determinants on voting behaviour in Britain (see, e.g., Clarke et al. 2004, 2009; Evans and Tilley 2012; Milazzo et al. 2012). Those who advocate the 'valence' theory of politics frequently stress the importance of party competence - the perceived ability of parties to deliver on their campaign commitments. All else being equal, voters prefer to cast their ballot for parties that are competent and that will govern effectively.

Clarke et al. (2009: 5) argue that "leader images serve as cost-effective heuristic devices or cognitive shortcuts that enable voters to judge the delivery capabilities of rival political parties". They demonstrate that assessments of the parties' leaders played an important role in explaining Labour's success in in the 2005 general election. The importance of party leaders was reinforced during the 2010 general election when voters had their first opportunity to witness live debates between the leaders of Britain's major parties, and empirical studies continue to document a strong relationship between leader performance and electoral choice (Clarke et al. 2011; Stevens et al. 2011).

\footnotetext{
${ }^{14}$ While including an image of the party leader may entail a trade-off in the terms of text, we find no evidence that leaflets featuring an image of the party leader are less likely to include an image of the party's local candidate.
} 
The fact that leader assessments weigh heavily in voters' minds cannot have escaped those crafting campaign content. Unfortunately, not all leaders are equally well-regarded, and the popularity of the party leader may be beyond a party's control by the time the campaign is underway. If candidates and election agents are strategic when designing the content of their communications, then we would expect a leader's national popularity to feature heavily in the decision to include the leader's photograph. Furthermore, we would expect this to be true regardless of whether the leaflet is designed according to a central party template or crafted by a candidate according to her own design. Party elites who know their leader is at a personal disadvantage vis-àvis her opponents should be less likely to feature the leader on their materials in general, and candidates should be less willing to devote space to a leader who is unlikely to strengthen the candidate's position with voters. Therefore, (H1) leaders who are popular nationally will be more likely to feature in election leaflets.

While national popularity should be the most important predictor of whether a leader appears in her party's leaflets, we also expect that strategic elites will take into account a leader's local appeal. As campaigns have modernised, parties become increasingly adept at targeting their resources (e.g., Fisher et al. 2011, 2015; Johnston et al. 2012) and content (Cowley and Kavanagh 2016). The popularity of party leaders varies considerably across the country, and even well-regarded leader may be more popular in some seats than they are in others. Prior to the start of the short campaign, David Cameron received more favourable ratings from BES respondents than Ed Miliband overall, but Cameron tended to be less popular than Miliband in northern constituencies, as well as those located in Scotland and Wales. Strategic elites should recognise that even a popular leader may be less of an asset in certain areas, and we would expect them to alter the content of their leaflets accordingly.

However, the leader's local appeal should be more likely to shape leaflet content in marginal constituencies for two reasons. First, when small shifts in votes can alter the outcome of the 
race, political elites have a stronger incentive to take voters' preferences into account when designing their campaign messages; aligning their content with voters views may help them attract additional support. Given the importance of leader evaluations in shaping voter behaviour (Clarke et al. 2004, 2009 Clarke et al. 2011; Stevens et al. 2011), a candidate contesting a marginal seat should be more willing to emphasise a leader who is popular with her voters - even if it comes at the expense of her own content - in the hopes that the emphasis will prime voters to consider the leader's positive image. If her leader is perceived be a liability, priming voters to consider a leader's poor image could cost her critical votes in a competitive environment. Second, parties spend far more time gathering information in marginal seats. Local parties are often active locally four to six months before the official campaign even begins (Johnston et al., 2012) or, in some cases, throughout the entire electoral cycle (Cutts 2006; Cutts et al. 2012). Extensive doorstep canvassing, leafleting, private polling, and public meetings give candidates and election agents more information about the views of their prospective voters, including voters' views of party leaders.

In safe seats, the messages disseminated by parties have less potential to effect the outcome of the race. Local popularity may still feature in a candidate's decision to include their leader in their leaflet, but including an unpopular leader is unlikely to have an effect on the outcome. As a result, candidates and local elites may be less concerned with ensuring a match between voters' preferences and their communication content, and local elites are less likely to have nuanced information regarding voters' views of the leaders. Therefore, $(\mathrm{H} 2)$ party leaders who are popular locally will be more likely to feature in election leaflets, but the effect of local popularity should be stronger effect in marginal seats.

While our arguments thus far relate to party or the context of the election, characteristics of the party's local candidate may also influence the decision to include a photograph of the party leader. If the party's candidate has a personal advantage, then election communications may be more likely to emphasise these traits. For example, MPs spend roughly half of their time working 
in their constituency or working on constituency issues (Rosenblatt 2006). If the party's candidate is the incumbent MP, then her election materials may stress actions taken on behalf of her constituents, as British voters tend to value such services (e.g., Cain et al. 1987; Wood and Norton 1992; Heitshusen et al. 2005). Similarly we know that voters value local connections (Arzheimer and Evans 2012; Campbell and Cowley 2014; Childs and Cowley 2011; Cowley 2013). Despite of the fact that there is no local residence requirement for candidature in Britain, Johnson and Rosenblatt (2007) find that local ties are consistently amongst the most important characteristics that voters look for in their candidates. Given that electoral communications contain limited content, those designing election communications may not wish to devote space to the party leader if the local candidate possesses the advantage of local connections. Thus, (H3) party leaders will be less likely to feature in leaflets distributed by incumbents and candidates with local connections to the constituency.

\section{Empirical analyses}

In order to test whether leaders who are perceived to be more popular nationally are more likely to appear in election communications, we compare the percentage of each party's leaflets that contain an image of the party's leader against the percentage of all BES respondents and party supporters who indicated that they "liked" the party leader (Figure 2). ${ }^{15}$ The comparison indicates that there is considerable variation in the degree to which party leaders appear in election communications and that this variation is broadly consistent with $\mathrm{H} 1$ - i.e., popular leaders appear more frequently.

Of the parties included in our dataset, the SNP was the most likely to feature its leader in its communications - Nicola Sturgeon appeared in two-thirds of SNP leaflets in our dataset. Sturgeon was also considerably more popular amongst all respondents and her own supporters than

\footnotetext{
${ }^{15}$ The question reads, 'How much do you like or dislike each of the following party leaders?' Higher numbers indicate that the respondent had a more favourable impression of the leader.
} 
her counterparts. After Sturgeon, David Cameron was most likely to feature in his party's communications. More than 40 per cent of the Conservative communications we examined include an image of the Prime Minister. He was also the second most popular leader amongst the public.

[Figure 2 here]

The remaining leaders were considerably less popular and featured less frequently in their party's leaflets, but the correlation between popularity and leader presence is not perfect. The Green Party leader, Natalie Bennett, was less popular than the other leaders, and yet she featured in more than a third of the party's communications in our dataset. In contrast, very few communications from Labour, UKIP, or the Liberal Democrats contain an image of the party's leader. Arguably, these same parties also struggled most significantly with the unpopularity of their leader in the months preceding the general election. Nigel Farage was well liked by his supporters, but his evaluations amongst the general public were considerably less favourable. Whilst the Labour leader, Ed Miliband, was the third most popular leader overall, his ratings amongst his own supporters were lower than any other party leader except Nick Clegg. The Deputy Prime Minister was unpopular with both the public and his own supporters. The popularity of these two leaders or lack thereof - amongst their own supporters would have made them a risky bet for campaigners seeking to use electoral communications to secure the support of those who had voted for the parties in previous elections.

That being said, all leaders experience varying levels of popularity across constituencies. We measure a leader's local popularity by taking the average likeability rating of the leader across all BES respondents in the constituency. Table 1 presents the percentage of leaflets that include a photograph of the party leader in seats where the leader's local likeability is higher than the median likeability for all leaders vs. seats where the leader's local likeability falls below the median. We make this comparison for both marginal and safe seats. ${ }^{16}$ Consistent with $\mathrm{H} 2$, we

\footnotetext{
${ }^{16}$ Marginal seats are defined as constituencies where the margin of victory was less than 10points following the 2010 general election.
} 
find that local popularity has a stronger effect in marginal seats. Where the local context is competitive, there is nearly a 15-point difference between the two types of areas - i.e., 30.1 per cent of leaflets from areas where the leader's local popularity is above the median contain a photograph of the leader, compared with 15.3 per cent of leaflets in areas where the leader's local likeability is below the median. In safe seats, the difference declines to 10.5 points.

[Table 1 here]

Finally, we find limited support regarding the effect of candidate characteristics. If we take a simple measure of incumbency - the candidate is either an incumbent or she is not - we find that, contrary to $\mathrm{H} 4$, leaflets from incumbents are more likely to contain a photograph of the party leader. ${ }^{17}$ However, when we use an alternative measure of incumbency - the length of the incumbent's tenure as an MP - we observe a different pattern. Just 15 per cent of leaflets from candidates who have served as the constituency MP for more than 10 years include a photograph of the party leader, compared with 20 per cent of leaflets for candidates who served as the incumbent MP for less than a decade. We also find no evidence that candidates with local ties were hesitant to devote space to their party leader in their leaflets. Indeed, candidates who discussed their connections to the local community were more likely to also include a photograph of their party leader than candidates who made no reference to their party leader. ${ }^{18}$

The descriptive analyses above provide a preliminary test for our hypotheses regarding the personalisation of local campaign communications. However, the true value of our novel dataset is

\footnotetext{
${ }^{17}$ Data on incumbency and tenure is taken from the Parliamentary Candidates UK 2015 General Election Candidates dataset, v1. Available at: www.parliamentarycandidates.org/ [accessed 1 July 2017].

${ }^{18}$ We acknowledge that identifying local connections using leaflet content is an imperfect measure, but lack of overlap between our data and other sources of candidate data prevented us from employing alternative measures of local ties. However, given the well-known benefits associated with having local connections, we assume that candidates choose to emphasise any connections they may have with their constituency.
} 
that it allows us to engage in a more sophisticated and systematic analysis of communication content. Table 2 reports results of a series of logistic regression models, where the dependent variable is coded " 1 " if the leaflet contains a photograph of the party leader, and " 0 " otherwise. ${ }^{19}$ These estimates confirm that popular leaders appear more frequently (H1); Nicola Sturgeon and David Cameron are considerably more likely to appear in their parties' leaflets than the other leaders. In Table 3, we present the marginal effect of minimum/maximum change in each of the variables on the probability that a leaflet will contain a photograph of the party leader. An SNP leaflet is 36 percentage points more likely to include a photograph of the leader than a communication from a Labour party elite, while communications from the Conservatives and the Greens are 25 percentage points more likely to include such an image. For the parties with the least popular leaders - i.e., UKIP, Labour, and the Liberal Democrats - there are no meaningful differences in the likelihood that leader's photograph would appear in the election communications. Taken together, the predicted values and the model fit statistics indicate that party-level differences account for most of the variation in - and are the strongest predictors of - leader personalisation.

[Tables 2 and 3 here]

Even when we control for party-level effects, we still find interesting differences across constituencies. The multivariate analyses confirm that leader popularity has a stronger effect in marginal seats (H2). The coefficient associated with local likeability - the effect of local likeability when the margin of victory is equal to zero - is positive and statistical significant, indicating that leaders with more positive local ratings are more likely to appear in leaflets in marginal seats. The predicted values show that popular leaders are nearly 8 points more likely to appear in leaflets

\footnotetext{
${ }^{19}$ In models 3 and 4, we limit the analyses to include only the leaflets where the candidate is mentioned by name - i.e., leaflets we can be certain would have been counted against the candidate's election expenses.
} 
received in marginal seats than unpopular leaders. ${ }^{20}$ The same pattern is evident in safe seats, but the differences are more modest.

Finally, we find little support for our arguments regarding the effect of candidate characteristics (H3). Once we control for party-level differences and the effect of the local context, we find that candidates with local ties are more likely to include a photograph of their party leader, but we find limited evidence that incumbency has an effect on leader personalisation, regardless of how incumbency is operationalised. ${ }^{21}$

\section{Conclusion}

In this paper, we use a new dataset of British election leaflets - the largest collection available to date - to explore variation in campaign messaging. This is an important endeavour, as leaflets and other unsolicited materials are the main avenue of communication between voters and political elites during the campaign (Cowley and Kavanagh, 2016). Both parties and candidates devote the largest share of their budgets to this area. Moreover, nearly 90 per cent of the British Election Study respondents who were contacted by a political party during the campaign indicated that they had received a leaflet or letter from at least one party. ${ }^{22}$ And yet, despite the

\footnotetext{
${ }^{20}$ To identify a marginal and safe seat, we take the $10^{\text {th }}$ and $90^{\text {th }}$ percentiles of the margin of victory following the 2010 general election. This equates to a margin of victory of 3.6 and 34.2, respectively.

${ }^{21}$ In supplementary analyses, we re-estimate our main analyses using a Heckman selection model to account for the fact that certain types of constituencies may be more likely to 'select' into our dataset. The results support the findings from our original analysis and our conclusions remain unchanged.

${ }^{22}$ This figure outweighs the number of people who were contacted via other mediums, such as telephone (12 per cent) or email (34 per cent), as well as the number of people who reported that a party worker visited them in person at home (34 per cent) or engaged with them in the street (11 per cent). Figures are taken from wave 6 of the 2014-2017 British Election Study Internet Panel.
} 
prominence of election communications, there has been very little study of the messages contained in these materials. Our findings indicate that some voters are more likely than others to receive materials that emphasise the party leader. Parties and candidates are more likely to include photographs of the leader when their leader is popular nationally and among their own constituents, which suggests that political elites are strategic in their use of personalised material.

The variation in campaign content is important because it can shape the considerations that voters emphasise. By "priming" voters with certain types of information, elites alter the accessibility of the criteria for making political choices (Iyengar and Kinder, 1987; Krosnick and Kinder, 1990; Druckman, 2004). In doing so, elites influence the information that British voters weigh when evaluating their politicians (Stevens et al., 2011, Stevens and Karp, 2012). And, there is every reason to expect that variation in campaign message will have an effect. Scholars of British politics have repeatedly demonstrated that disparities in the intensity of local campaigns affect voter turnout (e.g., Fisher et al., 2011, 2015; Trumm and Sudulich, Forthcoming) and parties' vote share (e.g., Cutts, 2014; Fisher et al., 2011; Johnston et al., 2012). If there is variation in where campaigns are disseminating personalised appeals, then we might also expect to observe parallel variation in the degree to which voters rely on the personal characteristics of political elites when determining their vote choice (see, Takens et al., 2015).

While our data offer a unique and important window into the communication strategies of British parties, we do acknowledge its limitations. First, as discussed previously, these are selfreported data, meaning that we have no control over who uploads leaflets or where they are uploaded. However, supplementary analyses demonstrate that our results remain robust after controlling for a wide variety of potentially biasing factors. Second, while our dataset includes a large number - and a wide range - of electoral communications, this is nowhere near a complete count of leaflets distributed during the campaign. While there are no official figures of election communication distribution, based on a survey of election agents, Johnston et al. (2012) estimate 
that the main parties distributed 27-35 million leaflets and communications prior to the 2010 general election. ${ }^{23}$ The nature of our sample of convenience means that we must be cautious about drawing deterministic conclusions about the larger population of leaflets and parties' behaviour more generally. Finally, we are unable to determine who received the leaflets or why. British parties have become adept at using demographic data to personalise campaign materials (see, Cowley and Kavanagh 2016). Leaflets frequently ask voters to respond to questions about their views, while telephone banks and canvassers continually collect information about voters they contact. As a result, the profile of the individual receiving the material - rather than the characteristics of the constituency where the material is disseminated or the traits of the party's local candidate now plays a more significant role in determining the content of election leaflets than it did previous elections.

Despite these limitations, there are currently no other data available that allow us to explore messaging contained in these materials across a large number of constituencies in recent elections. Election communications are such a key point of interaction between voters and political elites during an election, that failure to gain insight into these messages leaves a significant gap in our understanding of how campaigns are conducted. More importantly, our data provide a unique avenue to explore the variation in the extent to which voters in different types of constituencies receive personalised information, and future research should consider whether voters in constituencies that receive a higher volume of personalised information are more likely to rely on this information when casting their ballot.

\footnotetext{
${ }^{23}$ Many of these leaflets would have been of the same design, distributed to households across the country.
} 


\section{Appendix}

Table A1. Distribution of election leaflets by party

\begin{tabular}{lcc}
\hline Party & Count & Per cent \\
\hline Conservative & 750 & 22.70 \\
Green & 373 & 11.29 \\
Labour & 891 & 26.97 \\
Lib Dem & 727 & 22.00 \\
SNP & 96 & 2.91 \\
UKIP & 467 & 14.13 \\
\hline Total & 3,304 & 100.00 \\
\hline
\end{tabular}




\section{References}

Ambady, Nalini, and Robert Rosenthal. 1993. "Half a Minute: Predicting Teacher Evaluations from Thin Slices of Nonverbal Behavior and Physical Attractiveness." Journal of Personality and Social Psychology 64: 431-31.

Arzheimer, Kai, and Jocelyn Evans. 2012. "Geolocation and Voting: Candidate - Voter Distance Effects on Party Choice in the 2010 General Election in England." Political Geography 31(5), 301-10.

Berglund, Frode, Sören Holmberg, Hermann Schmitt, and Jacques Thomassen. 2005. "Party Identification and Party Choice.” In J. Thomassen (Ed), The European Voter (pp. 105123). Oxford: Oxford University Press

Cain, Bruce, John Ferejohn, and Morris Fiorina. 1987. The Personal Vote: Constituency service and electoral independence. Cambridge, MA: Harvard University Press.

Campbell, Rosie, and Philip Cowley. 2014. "What Voters Want: Reactions to Candidate Characteristics in a Survey Experiment." Political Studies 62(4), 745-65.

Childs Sarah, and Philip Cowley. 2011. "The Politics of Local Presence: Is There a Case for Descriptive Representation?" Political Studies 59 (1), 1-19.

Clarke, Harold, David Sanders, Marianne Stewart, and Paul Whiteley. 2011. "Valence Politics and Electoral Choice in Britain, 2010." Journal of Elections, Public Opinion and Parties 21(2): 237-253.

Clarke, Harold, David Sanders, Marianne C. Stewart, and Paul. M. Whiteley. 2009. Performance Politics and the British Voter. Cambridge: Cambridge University Press.

Clarke, Harold, David Sanders, Marianne C. Stewart, and Paul. M. Whiteley. 2004. Political Choice in Britain. Oxford: Oxford University Press.

Cowley, Philip. 2013. "Why Not Ask the Audience? Understanding the Public's Representational Priorities." British Politics 8(2), 138-63.

Cowley, Philip, and Dennis Kavanagh. 2016. The British General Election of 2015. Basingstoke: Palgrave Macmillan.

Cutts, David. 2014. 'Local Elections as a 'Stepping Stone': Does Winning Council Seats Boost the Liberal Democrats' Performance in General Elections?” Political Studies 62(2): 361380.

Cutts, David. 2006. "Continuous Campaigning and Electoral Outcomes: The Liberal Democrats in Bath." Political Geography 25(1): 72-88.

Cutts, David, Ron Johnston, Charles Pattie, and Justin Fisher. 2012. "Laying the Foundations for Electoral Success: Conservative Pre-campaign Canvassing before the 2010 UK General Election." Journal of Elections, Public Opinion and Parties 22(3):359-75.

Dalton, Russell J., Ian McAllister, and Martin P. Wattenberg. 2000. "The Consequences of Partisan ealignment." In R.J. Dalton and M.P. Wattenberg (eds.), Parties Without Partisans: Political Change in Advanced Industrial Democracies (pp. 37-63). Oxford: Oxford University Press.

Dalton, Russell J., and Martin P. Wattenberg. 2002. "Unthinkable Democracy: Political Change in Advanced Industrial Democracies." In R.J. Dalton and M.P. Wattenberg (eds.), Parties Without Partisans: Political Change in Advanced Industrial Democracies (pp. 3-16). Oxford: Oxford University Press.

Deacon, David and Emily Harmer. 2014. National Press Coverage of UK General Elections (1918-2010): End Of Project Report For The Leverhulme Trust. Loughborough: Loughborough University Communication Research Centre.

Denver, David, Gordon Hands, and Ian MacAllister. 2004. "The Electoral Impact of Constituency Campaigning in Britain, 1992-2001.” Political Studies 52(2): 289-306.

Druckman, James N. 2004. "Priming the Vote: Campaign Effects in a US Senate Election." Political Psychology 25(4): 577-94.

Evans, Geoff, and James Tilley. 2012. "How Parties Shape Class Politics: Explaining the 
Decline of the Class Basis of Party Support.” British Journal of Political Science 42(1): 137-161.

Evans, Geoffrey and Robert Andersen. 2005. "The Impact of Party Leaders: How Blair Lost Labour Votes." Parliamentary Affairs 58(4): 818-36.

Fisher, Justin. 2005. "Literature Analysis: Content and Style." In E. Robinson and J. Fisher (eds.), General Election 2005: What the Voters Saw. London: Politics Network.

Fisher Justin, David Cutts, and Edward Fieldhouse. 2011. "The Electoral Effectiveness of Constituency Campaigning in the 2010 British General Election: The 'Triumph' of Labour? Electoral Studies 30(4): 816-828.

Fisher, Justin, Edward Fieldhouse, Ron Johnston, Charles Pattie, and David Cutts. 2015. "Is All Campaigning Equally Positive? The Impact of District Level Campaigning on Voter Turnout at the 2010 British General Election." Party Politics 22(2): 215-226.

Foley, Michael. 2000. The British Presidency. Manchester: Manchester University Press.

Graetz, Brian, and Ian McAllister. 1987 "Party Leaders and Election Outcomes in Britain, 19741983." Comparative Political Studies 19(4): 484-507.

Hamermesh, Daniel S., and Jeff E. Biddle. 1994. "Beauty and the Labor Market." The American Economic Review 84: 1174-94.

Heitshusen, Valerie, Garry Young, and David M. Wood. 2005. "Electoral Context and MP Constituency Focus in Australia, Canada, Ireland, New Zealand, and the United Kingdom." American Journal of Political Science 49(1): 32-45.

Heffernan, Richard and Paul Webb. 2005. "The British Prime Minister: The British Prime Minister: Much More than 'First Among Equals"'. In T. Poguntke and P. Webb (eds), The Presidentialization of Politics: A Comparative Study of Modern Democracies. Oxford: Oxford University Press.

Iyengar, Shanto, and Donald R. Kinder. 1987. News that Matters: Agenda-setting and Priming in a Television Age. Chicago: University of Chicago Press.

Johns, Robert and Mark Shephard. 2011. "Facing the Voters: The Potential Impact of Ballot Paper Photographs." Political Studies 59, 636-58.

Johnson Catherine, and Gemma Rosenblatt. 2007. "Do MPs Have the 'Right Stuff '?" Parliamentary Affairs 60(1):164-9.

Johnston, Ron, David Cutts, Charles Pattie, and Justin Fisher. 2012. "We've got them on the List: Contacting, Canvassing and Voting in a British General Election Campaign." Electoral Studies 31(2): 317-329.

Johnston, Ron J. and Charles Pattie. 2006. Putting Voters in their Place: Geography and Elections in Great Britain. Oxford: Oxford University Press.

Karvonen, Lauri. 2010. The Personalization of Politics. A Study of Parliamentary Democracies. Wivenhoe Park: ECPR Press.

Kavanagh, Dennis. 1970. Constituency Electioneering in Britain. London: Longmans.

Kriesi, Hanspeter. 2012. "Personalization of National Election Campaigns." Party Politics 18(6): 825-844.

Krosnick, Jon A., and Donald R. Kinder. 1990. "Altering the Foundations of Support for the President through Priming." American Political Science Review 84(2): 497-512.

Lenz, Gabriel S., and Chappell Lawson. 2011. "Looking the Part: Television Leads Less Informed Citizens to Vote Based on Candidates' Appearance." American Journal of Political Science 55(3): 574-89.

Marcus, George E., and Michael B. MacKuen. 1993. "Anxiety, Enthusiasm, and the Vote: The Emotional Underpinnings of Learning and Involvement during Presidential Campaigns." American Political Science Review 87(3): 672-85.

McAllister, Ian. 2007. “The Personalization of Politics.” In R.J. Dalton and H.D Klingemann (eds). The Oxford Handbook of Political Behaviour (pp. 577-88). Oxford: Oxford University Press. 
Olson, Ingrid R., and Christy Marshuetz. 2005. "Facial Attractiveness is Appraised in a Glance." Emotion 5(4): 498-502.

Mattes, Kyle, and Caitlin Milazzo. 2014. "Pretty Faces, Marginal Races: Predicting Election Outcomes using Trait Assessments of British Parliamentary Candidates." Electoral Studies 34(1): 177-89.

Milazzo, Caitlin, James Adams, and Jane Green. 2012. “Are Voter Decision Rules Endogenous to Parties' Policy Strategies? A Model with Applications to Elite Depolarization in PostThatcher Britain.” Journal of Politics 74(1): 262-276.

Panagopoulos, Costas. 2012. "Campaign Context and Preference Dynamics in U.S. Presidential Elections." Journal of Elections, Public Opinion and Parties 22(2): 123-37.

Pattie, Charles J., Ronald J. Johnston and Edward A. Fieldhouse. 1995. "Winning the Local Vote: The Effectiveness of Constituency Campaign Spending in Great Britain, 1983-1992." American Political Science Review 89(4): 969-83.

Rosenblatt, Gemma. 2006. A Year in the Life: From Member of Public to Member of Parliament. London: Hansard Society.

Shephard, Mark. 2007. "Multiple Audiences, Multiple Messages? An Exploration of the Dynamics between the Party, the Candidates and the Various Constituencies" Journal of Elections, Public Opinion and Parties 17(2): 181-201.

Stevens, Daniel and Jeffrey A. Karp. 2012. "Leadership Traits and Media Influence in Britain. Political Studies 60(4): 787-808.

Stevens, Daniel, Susan Banducci, Jeffrey Karp, and Jack Vowles. 2011. "Priming Time for Blair? Media Priming, Iraq, And Leadership Evaluations in Britain." Electoral Studies 30(3): 546-60.

Stevens, Daniel, Jeffrey A. Karp, and Robert Hodgson. 2011. "Party Leaders as Movers and Shakers in British Campaigns? Results from the 2010 Election." Journal of Elections, Public Opinion and Parties 21(2): 125-145.

Takens, Janet, Jan Kleinnijenhuis, Anita Van Hoof, and Wouter Van Atteveldt. 2015. "Party Leaders in the Media and Voting Behavior: Priming rather than Learning or Projection." Political Communication 32(2): 249-67.

Todorov, Alexander, Anesu N. Mandisodza, Amir Goren, and Crystal C. Hall. 2005. "Inferences of Competence from Faces Predict Election Outcomes." Science 308:1623-26.

Trumm, Siim, and Laura Sudulich. Forthcoming. "What does it take to make it to the polling station? The Effects of Campaign Activities on Electoral Participation." Party Politics.

Verser, Rebecca, and Robert H. Wicks. 2006. "Managing Voter Impressions: The Use of Images on Presidential Candidate Web Sites during the 2000 Campaign." Journal of Communication 56(1): 178-97.

Vliegenthart, Rens, Hajo G. Boomgaarden, and Jelle W. Boumans. 2011. "Changes in political news coverage: Personalization, conflict and negativity in British and Dutch newspapers." In L. Brants and K. Voltmer (eds.), Political Communication in Postmodern Democracy. Basingstoke: Palgrave Macmillan.

Wattenberg, Martin P. 1994. The Decline of American Political Parties, 1952-1992. Cambridge: Harvard University Press.

Wood, D., and P. Norton. 1992. "Do Candidates Matter? Constituency-specific Vote Changes for Incumbent MPs, 1983-1987.” Political Studies 40:227-38.

Wring, Dominic, and Stephen Ward. 2010. "The Media and the 2010 Campaign: The Television Election?" Parliamentary Affairs 63(4): 802-17. 
Figure 1. Distribution of leaflets by constituency

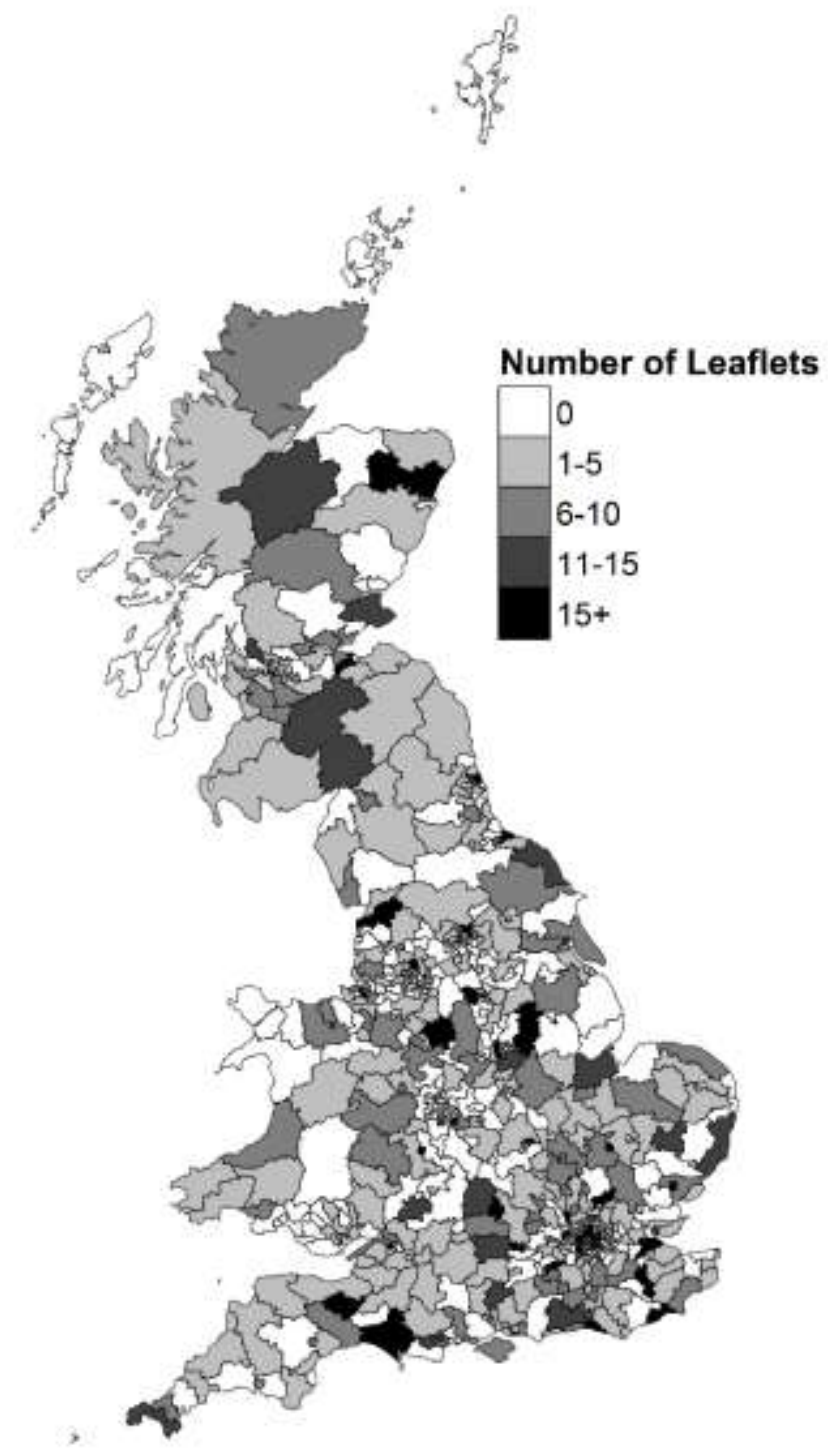


Figure 2. Leader personalisation and likeability, by party

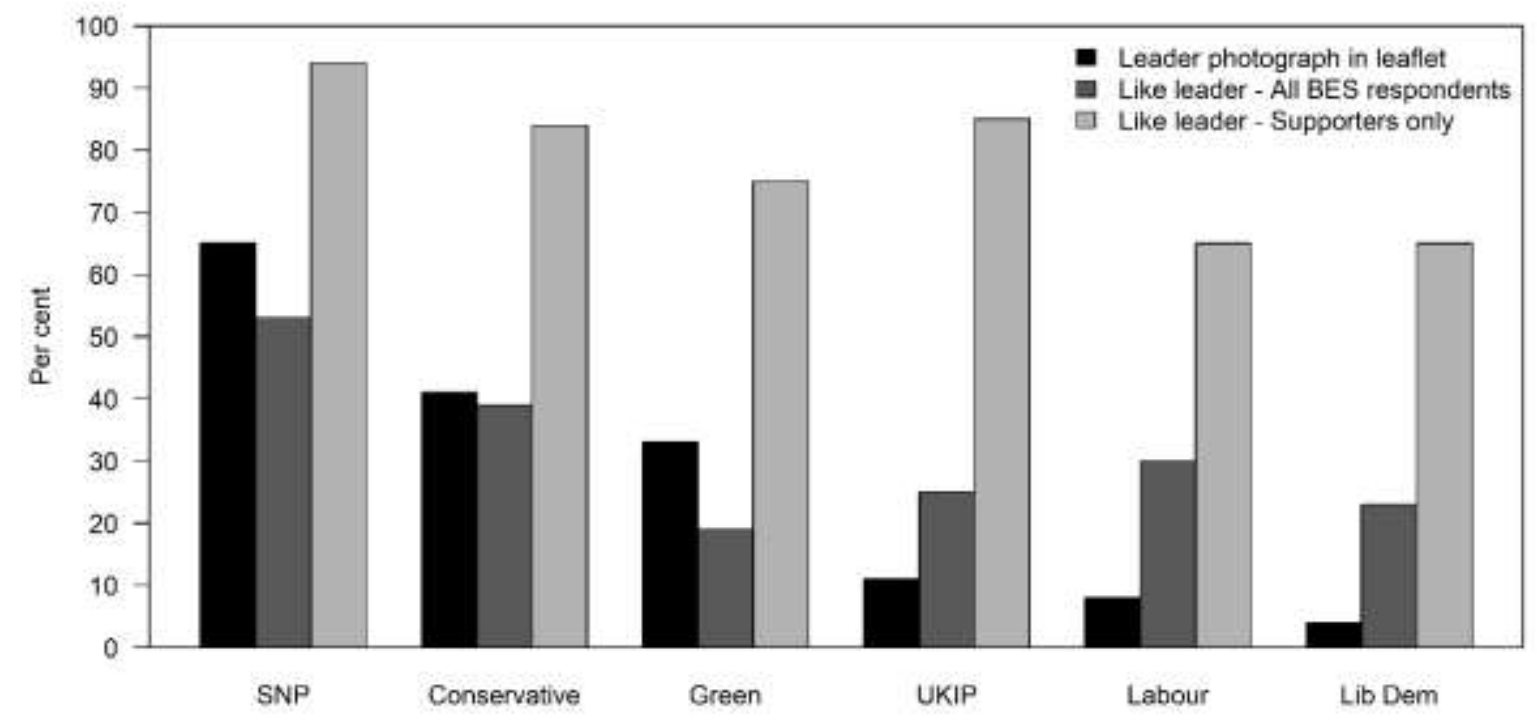

Source. Likeability data is taken from wave 4 of the 2014-2017 British Election Study Internet Panel. 
Table 1. Differences in leader personalisation

\begin{tabular}{lc}
\hline & $\begin{array}{c}\text { Leader photograph } \\
\text { included }(\%)\end{array}$ \\
\hline Marginal seats & 30.1 \\
High local likeability & 15.3 \\
Low local likeability & $+14.8^{* *}$ \\
Difference & \\
Safe seats & 23.1 \\
High local likeability & 12.6 \\
Low local likeability & $+10.5^{* *}$ \\
Difference & \\
Incumbent & 22.5 \\
Yes & 18.4 \\
No & $+4.1^{* *}$ \\
Difference & \\
Tenure in parliament & 15.1 \\
More than 10 years & 19.8 \\
0-10 years & -4.7 \\
Difference & \\
Local ties to constituency & 25.9 \\
Yes & 16.9 \\
No & $+9.0^{* *}$ \\
Difference & \\
\hline
\end{tabular}

Notes. $* * \mathrm{p}<0.01$. 
Table 2. Logistic regression model of leader personalisation

\begin{tabular}{|c|c|c|c|c|c|}
\hline \multirow{2}{*}{$\begin{array}{l}\text { Variables } \\
\text { Party (ref: Labour) }\end{array}$} & \multirow[t]{2}{*}{$\begin{array}{l}(1) \\
\text { Party } \\
\text { only }\end{array}$} & $\begin{array}{c}\text { (2) } \\
\text { Local context } \\
\text { only }\end{array}$ & \multicolumn{2}{|c|}{$\begin{array}{c}\text { (3) } \\
\begin{array}{c}\text { Candidate traits } \\
\text { only }\end{array} \\
\end{array}$} & \multirow[t]{2}{*}{$\begin{array}{c}(4) \\
\text { Full } \\
\text { model } \\
\end{array}$} \\
\hline & & & & & \\
\hline Conservative & $\begin{array}{c}2.12 * * \\
(0.15)\end{array}$ & & & & $\begin{array}{c}2.48 * * \\
(0.20)\end{array}$ \\
\hline Liberal Democrat & $\begin{array}{c}-0.74 * * \\
(0.23)\end{array}$ & & & & $\begin{array}{l}-0.07 \\
(0.28)\end{array}$ \\
\hline SNP & $\begin{array}{c}3.08 * * \\
(0.25)\end{array}$ & & & & $\begin{array}{c}2.97 * * \\
(0.35)\end{array}$ \\
\hline UKIP & $\begin{array}{l}0.42 * \\
(0.19)\end{array}$ & & & & $\begin{array}{c}0.41 \\
(0.30)\end{array}$ \\
\hline Green & $\begin{array}{l}1.76^{* *} \\
(0.17)\end{array}$ & & & & $\begin{array}{l}2.46^{* *} \\
(0.23)\end{array}$ \\
\hline Local popularity & & $\begin{array}{c}0.64 * * \\
(0.11)\end{array}$ & & & $\begin{array}{c}0.36 * * \\
(0.12)\end{array}$ \\
\hline 2010 Margin of victory & & $\begin{array}{l}-0.01 \\
(0.02)\end{array}$ & & & $\begin{array}{l}-0.01 \\
(0.02)\end{array}$ \\
\hline Local popularity*Margin of victory & & $\begin{array}{l}-0.00 \\
(0.00)\end{array}$ & & & $\begin{array}{l}-0.00 \\
(0.01)\end{array}$ \\
\hline Incumbent & & & $\begin{array}{c}0.34 * * \\
(0.10)\end{array}$ & & $\begin{array}{c}0.25 \\
(0.15)\end{array}$ \\
\hline MP more than 10 years & & & & $\begin{array}{l}-0.17 \\
(0.19)\end{array}$ & \\
\hline Local ties & & & $\begin{array}{c}0.59 * * \\
(0.09)\end{array}$ & $\begin{array}{l}0.74 * * \\
(0.10)\end{array}$ & $\begin{array}{c}0.81 * * \\
(0.12)\end{array}$ \\
\hline Constant & $\begin{array}{c}-2.48 * * \\
(0.13)\end{array}$ & $\begin{array}{c}-3.79 * * \\
(0.43)\end{array}$ & $\begin{array}{c}-1.70 * * \\
(0.07)\end{array}$ & $\begin{array}{l}1.78 * * \\
(0.07)\end{array}$ & $\begin{array}{c}-4.56 * * \\
(0.53)\end{array}$ \\
\hline$N$ & 3,304 & 3,304 & 3,304 & 2,723 & 2,723 \\
\hline McFadden $R^{2}$ & 0.18 & 0.04 & 0.01 & 0.02 & 0.24 \\
\hline$\%$ Correctly classified & 81.42 & 80.51 & 81.71 & 81.71 & 83.47 \\
\hline
\end{tabular}

Notes. Robust standard errors are given in parentheses. $* \mathrm{p}<0.05 * * \mathrm{p}<0.01$. Models 3 and 4 are limited to leaflets where the candidate is mentioned by name. 
Table 3. Predicted change in leader personalisation

\begin{tabular}{lrc}
\hline Variables & Min/max $\Delta$ & \\
\hline Party (ref: Labour) & & \\
$\quad$ Conservative & +0.25 & $* *$ \\
Liberal Democrat & -0.00 & \\
SNP & +0.36 & $* *$ \\
UKIP & +0.02 & \\
Green & +0.25 & $* *$ \\
Local popularity - Marginal seat & +0.08 & $*$ \\
Local popularity - Safe seat & +0.05 & $*$ \\
Incumbent & +0.01 & \\
Local ties & +0.04 & $* *$ \\
\hline
\end{tabular}

Notes. Marginal effects are calculated using the estimates from model 4 in Table 3. $* \mathrm{p}<0.05 * *$ $\mathrm{p}<0.01$. 